\title{
IMPACT OF SEEDLINGS AGE ON VEGETABLE MARROW PRODUCTION
}

\author{
G. Jellani, H. Ullah, M. Ali ${ }^{1}$, T.N. Khan, \\ M.J. Atif and M. Musa ${ }^{* 2}$ \\ Horticultural Research Institute, National Agricultural Research Center (NARC), Islamabad, Pakistan
}

\begin{abstract}
A study was conducted at the research field of Horticultural Research Institute, National Research Center (NARC), Islamabad, Pakistan during two consecutive years of 2011 and 2012 to compare the performance of seedlings raised in polythene bags with traditional direct seeding in respect of early harvesting and profitability. Seedlings of three different ages (40, 50 and 60 days old) of vegetable marrow were compared with traditional direct seeded crop. Transplanted seedlings of vegetable marrow produced fruits 36-38 days earlier and availability period of 34-38 days longer than direct seeded crop. Similarly, higher fruit plant ${ }^{-1}$, fruit weight plant ${ }^{-1}$ and fruit yield ha ${ }^{-1}$ were obtained from seedling treatments. Averaged over years, $50-69 \%$ increase in yield and $64-100 \%$ increase in profit were recorded in seedling treatments than direct seeded crop. Among seedling ages, 60 days old seedlings were the best performer. The overall results of two years study revealed that seedling transplantation was superior to traditional direct seeded practice of growing vegetable marrow and among those 60 days old seedlings was the best in respect of yield components, fruit yield and profit.
\end{abstract}

Keywords: Cucurbits, Vegetable marrow, Early crop, Gross return,

Seedlings

\section{INTRODUCTION}

The demand for vegetables is increasing due to enhancement in prosperity, leading to the intensification of production and higher profitability. With better profitability, the application of mulch, drip irrigation, fertigation and protected cultivation seems to be indispensable. Harvest date planning related to year-round city market demand is essential to improve profitability. It is recommended that research and extension on vegetables in tropical Asia, next to the development and

\footnotetext{
* Corresponding author email: mum96@ hotmail.com

${ }^{1}$ AVRDC-The World Vegetable Center-Pakistan Office, Islamabad, Pakistan

${ }^{2}$ Agronomist, Barani Agricultural Research Institute, Chakwal, Pakistan

Received: 31.03 .2015
} 
introduction of improved production technologies, should focus on methods to improve harvest date planning and year-round supply (Everaarts and Putter, 2009).

In Pakistan, cucurbits including vegetable marrow, bitter gourd, cucumber etc are traditionally grown through seeds during the month of February-March. Seedlings of these vegetables are not in practice on soil beds because these vegetables cannot tolerate slight damage to their root and shoot system during their uprooting and transplanting. Due to late planting, markets are flooded with such cucurbitaceous vegetables during the month of May and June, and the growers are not getting reasonable profit. Early harvest of even 10-15 days can fetch a good price for these vegetable produce. Previously, Leskovar et al. (1991) conducted a trial with two to six weeks old seedlings of tomato and found no improvement in yields by using the traditional older transplants. Younger transplants might be used to achieve rapid seedlings establishment with minimal transplant production costs. Similarly, Nesmith (1993) stated that transplants of varying ages did not differ greatly in yield and yield components in the field although all transplants had higher early yields than the directly seeded controls in summer squash. Therefore, the experiment was conducted to compare the performance of seedlings raised in polythene bags with traditional direct seeding in respect to early harvesting and profitability.

\section{MATERIAL AND METHODS}

The experiment was conducted during two consecutive years of 2011 and 2012 at the research field of Horticultural Research Institute, National Agricultural Research Center, Islamabad, Pakistan (Latitude: $33.42^{\circ} \mathrm{N}$; Longitude: $73.08^{\circ} \mathrm{E}$; Elevation: $683 \mathrm{msl}$ ). The soil of the experimental field was loam in texture with $\mathrm{pH}$ 7.4. Three different seedlings ages viz., 40 days old seedlings $\left(T_{2}\right), 50$ days old seedlings $\left(\mathrm{T}_{3}\right)$ and 60 days old seedlings $\left(\mathrm{T}_{4}\right)$ were tested with traditional direct seeded practice $\left(\mathrm{T}_{1}\right)$ under field conditions.

Seedlings of vegetable marrow were raised in polythene bags under simple and low cost protected structures (walk in tunnels) during the month of January/February in both the years. The experiment was laid out in a randomized complete block design (RCBD) with three replications. The unit plot size was $2 \mathrm{~m} \times 3 \mathrm{~m}$. Farm yard manure @ $7 \mathrm{t} \mathrm{ha}^{-1}$ was incorporated into the soil as organic amendment. Seeds or seedlings of different aged of vegetable marrow (cv. Local) was sown or transplanted during first week of March in both the years maintaining row to row and plant to plant distance of $100 \mathrm{~cm}$ and $60 \mathrm{~cm}$, respectively. Intercultural operations like watering, weeding and pest control etc. were done as and when required. First harvesting of vegetable marrow was done at 64-65 days after sowing (DAS) in case of direct seeding and at 22-31 days after transplanting in case of seedlings by hand picking. Data on yield components were collected from randomly selected three plants from each plot. Yield data were taken from whole plot. The collected data were analyzed statistically using statistic 8.1 software package. Means of different 
parameters were ranked according to Least Significant Difference (LSD) Test (Steel et al., 1997). Cost and return analysis was also performed based on prevailing market price of vegetable marrow.

\section{RESULTS AND DISCUSSION}

In a two years study, seedlings of different ages showed a significant effect on days to first picking (Table 2). It is evident from the results that seedlings of different ages responded differently as year changes. The seedlings of 60 days old produced earlier fruits compared to 40 and 50 days old seedlings as well as direct seeded crop during 2011. It is also clear from the two years mean values that seedlings irrespective of their age produced fruits earlier compared to direct seeded crop (Table 2). Singh et al. (2010) also proved the technique of raising seedlings for early harvesting of cucurbit in India. The difference in days to first picking during both years might be due to difference in temperature (Table 1). The higher temperature during growth period in 2011 enhanced the early production of pistillate flowers leading to early harvesting. Nesmith \& Hoogenboom (1994) also stated that production of pistillate flowers in summer squash was accelerated by high temperature. Availability period of vegetable marrow was also influenced significantly by seedlings age. Seedlings of 60 days old gave the longest availability period and it decreased with decreasing seedlings age in both the years (Table 2). The shortest availability period was recorded in direct seeded crop. Availability period of different aged seedlings were longer in 2011 than those in 2012 probably for higher temperature. The mean availability period for 60 days old seedlings was longest (97.00 days) followed by 50 days one. Similar results were also reported by Singh et al. (2010). Significantly higher survival rate $(100 \%)$ was recorded in three seedling transplantation treatments compared with direct seeded crop $(81.7 \%)$. Higher survival rate contributed to increase production per unit area of vegetable marrow.

Yield contributing characters like number of fruits plant $^{-1}$ and fruit weight plant $^{-1}$ varied significantly due to seedlings age and direct seeded crop (Table 3). Maximum fruits plant $^{-1}$ was recorded in 60 days old seedlings while the minimum in direct seeded crop in both years. Fruits plant ${ }^{-1}$ was more in 2012 than in 2011 in all treatments except direct seeded crop. The mean value for fruits plant $^{-1}$ was also the highest in 60 days old seedlings as compared to other treatments. Fruit weight plant ${ }^{-1}$ was recorded maximum in 50 days old seedlings during 2011 while in 60 days old seedlings during 2012. But fruit weight plant $^{-1}$ in 50 and 60 days old seedlings were statistically identical in both years. Considering mean values for fruit weight plant $^{-1}$, 60 and 50 days old seedlings were better compared to 40 days old seedlings as well as direct seeded crop. More fruits plant ${ }^{-1}$ and fruit weight plant ${ }^{-1}$ in these treatments might be due to early flowering and longer availability period of the crop. Similar to fruit plant ${ }^{-1}$, the highest mean fruit yield ha ${ }^{-1}$ was recorded in 60 days old seedlings followed by 50 and 40 days old seedlings while the difference between 50 and 40 days old seedlings was not statistically significant (Table 4). The higher yields ha ${ }^{-1}$ in 
seedling treatments was attributed to the fruit weight plant $^{-1}$ and survival percentage. Leskovar et al. (1991) also reported similar results in tomato.

The highest mean gross return $\mathrm{ha}^{-1}$ was recorded in 60 days old seedlings, which was followed by 50 and 40 days old seedlings. The lowest mean gross return $\mathrm{ha}^{-1}$ was obtained from direct seeded crop owing to the lowest yield ha ${ }^{-1}$ (Table 4). Higher mean gross margins ha $^{-1}$ were recorded in 60 and 50 days old seedlings as compared to 40 days old seedlings and direct seeded crop (Table 4). Averaged over years, 50-69\% increase in yield and 64-100\% increase in profit were recorded in seedling treatments as compared to direct seeded crop (Figure 1) while crop with 60 days old seedlings treatment remained at the top with $69 \%$ increase in yield and $100 \%$ increase in profit compared to direct seeded crop. This might be due to all yield contributing factors, which were at maximum with 60 days old seedling treatment. Nesmith (1993) also reported the similar results in summer squash.

\section{CONCLUSION}

The overall results of two years study revealed that seedling transplantation was superior to traditional direct seeded practice of growing vegetable marrow and among those, 60 days old seedlings was the best in respect of fruit yield and profit.

\section{REFERENCES}

Everaarts, A.P. and de Putter, H. 2009. Opportunities and constraints for improved vegetable production technology in tropical Asia. Acta Horticulture (ISHS), 809:55-68. (http://www.actahort.org/books/809/809_3.html)

Leskovar, D.I., Daniel, J. Cantliffe and Stoffella, P.J. 1991. Growth and yield of tomato plants in response to age of transplants._Journal of the American Society for Horticultural Science, 116(3):416-420

Nesmith, D.S. and Hoogenboom, G. 1994. Staminate and Pistillate flower production of summer. squash in response to planting dates. Horticulture Science, 29(4): 256-257

Nesmith, D.S. 1993. Transplant age influences summer squash growth and yield. Horticulture Science, 28(6):618-620

Singh, B., Tomar, B.S. and Hasan, M. 2010. Plug tray nursery raising technology for off season cucurbits cultivation. Acta Horticulture, (ISHS), 871:279-282. (http://www.actahort.org/books/871/871_37.htm) 
Table 1. Meteorological data during the study period of 2011 and 2012

\begin{tabular}{l|c|c|c|c}
\hline \multicolumn{1}{c|}{ Period of study } & $\begin{array}{c}\text { Maximum } \\
\text { Temperature } \\
\left({ }^{\circ} \mathbf{C}\right)\end{array}$ & $\begin{array}{c}\text { Minimum } \\
\text { Temperature } \\
\left({ }^{\circ} \mathbf{C}\right)\end{array}$ & $\begin{array}{c}\text { Relative } \\
\text { Humidity } \\
(\boldsymbol{\%})\end{array}$ & $\begin{array}{c}\text { Rainfall } \\
(\mathbf{m m})\end{array}$ \\
\hline January, 2011 & 17.3 & 01.8 & 71.3 & 08.32 \\
February, 2011 & 17.7 & 05.8 & 75.8 & 78.73 \\
March, 2011 & 25.8 & 10.2 & 63.0 & 53.19 \\
April, 2011 & 28.8 & 13.5 & 61.0 & 53.96 \\
May, 2011 & 38.1 & 20.4 & 45.0 & 17.29 \\
January, 2012 & 16.9 & 01.3 & 68.5 & 59.06 \\
February, 2012 & 17.4 & 03.2 & 70.1 & 44.12 \\
March, 2012 & 24.9 & 08.9 & 58.6 & 15.95 \\
April, 2012 & 29.9 & 15.0 & 54.7 & 40.93 \\
May, 2012 & 26.2 & 18.3 & 38.4 & 09.47 \\
\hline
\end{tabular}

Source: Meteorological Section, Climate Change, Alternate Energy \& Water Resources Institute (CAEWRI), NARC, Islamabad, Pakistan.

Table 2. First harvest, availability period and survival rate of vegetable marrow as influenced by seedling age

\begin{tabular}{l|c|c|c|c|c|c|c|c|c}
\hline Treatment & $\begin{array}{c}\text { Seeding/transplanting } \\
\text { to first picking } \\
\text { (Days) }\end{array}$ & \multicolumn{3}{c|}{$\begin{array}{c}\text { Availability Period } \\
\text { (Days) }\end{array}$} & \multicolumn{3}{c}{$\begin{array}{c}\text { Survival rate of plants } \\
(\%)\end{array}$} \\
& $\mathbf{2 0 1 1}$ & $\mathbf{2 0 1 2}$ & Mean & $\mathbf{2 0 1 1}$ & $\mathbf{2 0 1 2}$ & Mean & $\mathbf{2 0 1 1}$ & $\mathbf{2 0 1 2}$ & Mean \\
\hline $\mathrm{T}_{1}$ & 63.33 & 64.66 & 64.00 & 56.66 & 61.33 & 59.00 & 83.33 & 83.00 & 83.17 \\
$\mathrm{~T}_{2}$ & 26.00 & 30.00 & 28.00 & 94.00 & 92.00 & 93.00 & 100.00 & 100.00 & 100.00 \\
$\mathrm{~T}_{3}$ & 24.33 & 29.33 & 26.83 & 95.66 & 93.33 & 94.50 & 100.00 & 100.00 & 100.00 \\
$\mathrm{~T}_{4}$ & 22.00 & 31.00 & 26.50 & 98.00 & 96.00 & 97.00 & 100.00 & 100.00 & 100.00 \\
$\mathrm{LSD}_{(0.05)}$ & 1.68 & 1.69 & 1.58 & 1.42 & 1.30 & 1.46 & 2.49 & 2.49 & 2.49 \\
\hline
\end{tabular}

$\mathrm{T}_{1}=$ Traditional direct seeded practice, $\mathrm{T}_{2}=40$ days old seedlings, $\mathrm{T}_{3}=50$ days old seedlings, $\mathrm{T}_{4}=60$ days old seedlings 
Table 3. Yield components of vegetable marrow as influenced by seedling age

\begin{tabular}{|c|c|c|c|c|c|c|c|c|c|}
\hline \multirow[t]{2}{*}{ Treatment } & \multicolumn{3}{|c|}{$\begin{array}{l}\text { Fruits plant }{ }^{-1} \\
\text { (no.) }\end{array}$} & \multicolumn{3}{|c|}{$\begin{array}{l}\text { Fruit weight plant }{ }^{-1} \\
\text { (g) }\end{array}$} & \multicolumn{3}{|c|}{$\begin{array}{l}\text { Single fruit weight } \\
\text { (g) }\end{array}$} \\
\hline & 2011 & 2012 & Mean & 2011 & 2012 & Mean & 2011 & 2012 & Mean \\
\hline $\mathrm{T}_{1}$ & 13.33 & 07.66 & 10.50 & 561.10 & 755.83 & 658.47 & 116.9 & 107.7 & 112.3 \\
\hline $\mathrm{T}_{2}$ & 25.66 & 27.33 & 27.33 & 720.77 & 848.53 & 784.65 & 109.9 & 112.3 & 111.1 \\
\hline $\mathrm{T}_{3}$ & 27.33 & 35.66 & 31.50 & 778.30 & 899.30 & 838.80 & 118.8 & 110.8 & 114.8 \\
\hline $\mathrm{T}_{4}$ & 37.66 & 41.66 & 39.66 & 764.90 & 985.27 & 875.08 & 112.5 & 121.8 & 117.2 \\
\hline $\operatorname{LSD}_{(0.05)}$ & 2.18 & 3.24 & 4.48 & 52.12 & 96.71 & 95.93 & NS & NS & NS \\
\hline
\end{tabular}

NS indicates not significant, $\mathrm{T}_{1}=$ Traditional direct seeded practice, $\mathrm{T}_{2}=40$ days old seedlings, $\mathrm{T}_{3}=50$ days old seedlings, $\mathrm{T}_{4}=60$ days old seedlings

Table 4. Fruit yield and benefit cost analysis of vegetable marrow as influenced by seedling age

\begin{tabular}{|c|c|c|c|c|c|c|c|c|c|}
\hline \multirow[t]{2}{*}{ Treatment } & \multicolumn{3}{|c|}{$\begin{array}{c}\text { Fruit yield } \\
\left(\mathrm{t} \mathrm{ha}^{-1}\right)\end{array}$} & \multicolumn{3}{|c|}{$\begin{array}{l}\text { Gross return } \\
\left(000 \text { Rs. ha }{ }^{-1}\right)\end{array}$} & \multicolumn{3}{|c|}{$\begin{array}{l}\text { Gross margin } \\
(000 \text { Rs. ha } \\
\end{array}$} \\
\hline & 2011 & 2012 & Mean & 2011 & 2012 & Mean & 2011 & 2012 & Mean \\
\hline $\mathrm{T}_{1}$ & 11.66 & 16.13 & 13.90 & 143.8 & 209.5 & 176.7 & 38.6 & 90.7 & 64.7 \\
\hline $\mathrm{T}_{2}$ & 19.20 & 22.63 & 20.91 & 249.3 & 294.0 & 271.7 & 88.7 & 123.8 & 106.2 \\
\hline $\mathrm{T}_{3}$ & 20.36 & 23.96 & 22.16 & 266.6 & 311.6 & 289.1 & 100.9 & 136.4 & 118.7 \\
\hline $\mathrm{T}_{4}$ & 20.73 & 26.26 & 23.50 & 268.7 & 341.4 & 355.1 & 98.1 & 161.2 & 129.6 \\
\hline $\operatorname{LSD}_{(0.05)}$ & 1.54 & 1.78 & 1.30 & 60.2 & 45.3 & 68.4 & 12.8 & 23.2 & 17.5 \\
\hline
\end{tabular}

$\mathrm{T}_{1}=$ Traditional direct seeded practice, $\mathrm{T}_{2}=40$ days old seedlings, $\mathrm{T}_{3}=50$ days old seedlings, $\mathrm{T}_{4}=60$ days old seedlings, Market price of vegetable marrow: $12-14 \mathrm{Rs} . \mathrm{kg}^{-1}$ 


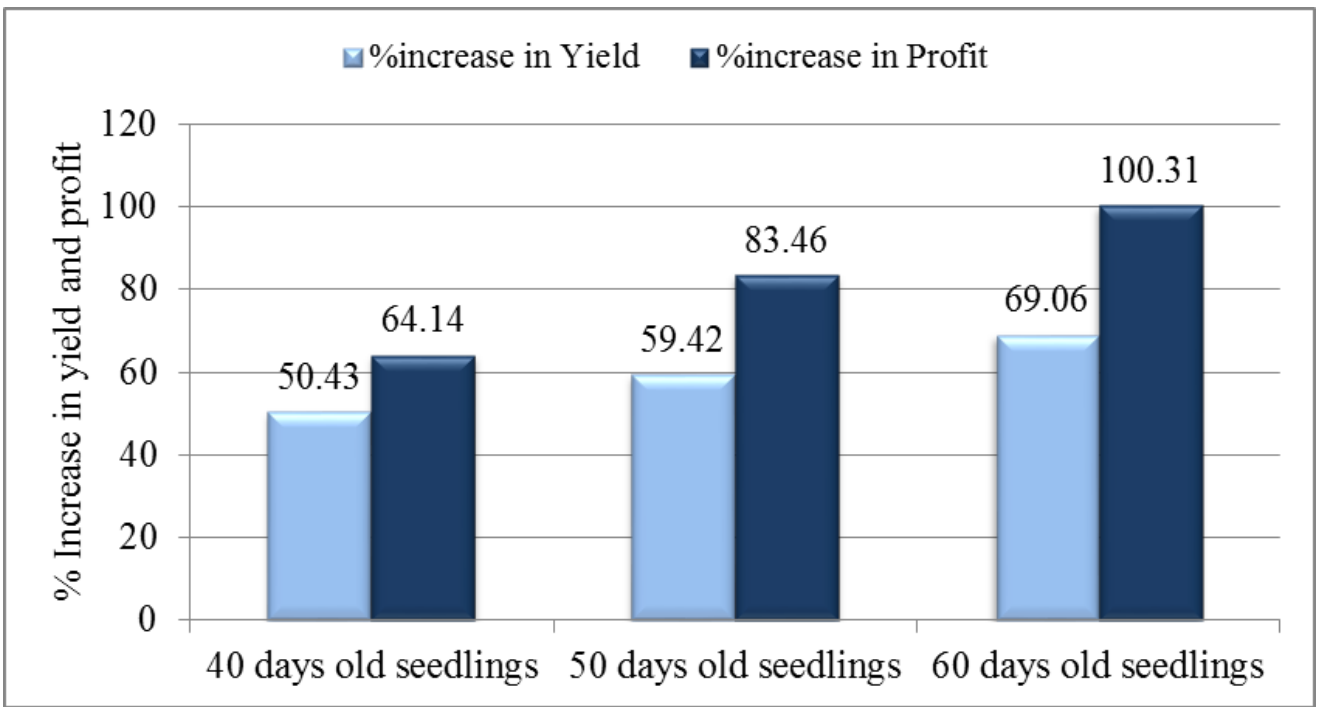

Figure 1. Increase in yield and profit of vegetable marrow from different aged seedlings compared to direct sowing (2-year average) 